MaPan : Jurnal Matematika dan Pembelajaran

p-ISSN: 2354-6883 ; e-ISSN: 2581-172X

Volume 9, No 2, Dec 2021 (260-279)

DOI: https://doi.org/10.24252/mapan.2020v8n2a5

\title{
CALCULUS LEARNING VIA SCREENCAST-O-MATIC DURING THE PANDEMIC: AN EXPLORATION TOWARDS STUDENTS' PERCEPTION OF MATH ANXIETY
}

\author{
Robert Harry Soesanto1), Kurnia Putri Sepdikasari Dirgantoro') \\ 1,2Department of Mathematics Education, Universitas Pelita Harapan \\ 1,2J1. M. H. Thamrin 1100, Tangerang, Indonesia \\ Email: robert.soesanto@uph.edu11),kurnia.dirgantoro@uph.edu²)
}

Received November 26, 2021; Revised December 27, 2021; Accepted December 28, 2021

\begin{abstract}
:
The emergence of the Covid-19 pandemic has transformed the learning system into an online mode, where students' anxiety became the spotlight for educators to create a learning environment that actively engages them. Many educators are competing in maximizing the use of technology to ensure students are engaged in the learning process. The study aims to explore students' perception of math anxiety through the implementation of Screencast-O-Matic in calculus learning. This study involves 41 students at the university level and is conducted in mixed methods, using statistics and narrative descriptives. Questionnaires and open-ended questions are used to investigate students' testimonies about the video made by Screencast-O-Matic and their perceptions of math anxiety after learning with the video given. The results showed that the implementation of Screencast-O-Matic video gradually reduces students' mathematics anxiety during online calculus learning. Screencast-O-Matic offers educators the opportunity to build a web-based lecture learning system in audio-visual media to minimize students' anxiety levels. Furthermore, the most important things to consider while creating an educational video are clarity of message, user-friendliness, good visualization, and easy access to students anytime and anywhere.
\end{abstract}

Keywords: Mathematics Anxiety, Screencast-O-Matic, Learning Video, Calculus, Pandemic Issue

\section{PEMBELAJARAN KALKULUS VIA SCREENCAST-O-MATIC SELAMA PANDEMI: EKSPLORASI TERHADAP PERSEPSI KECEMASAN MATEMATIS MAHASISWA}

\begin{abstract}
Abstrak:
Kemunculan pandemi covid-19 telah mengubah sistem pembelajaran menjadi daring, dimana kecemasan peserta didik menjadi sorotan bagi pendidik untuk menciptakan lingkungan pembelajaran yang melibatkan mereka secara aktif. Para pendidik bersaing dalam memaksimalkan penggunaan teknologi untuk memastikan siswa terlibat pada proses pembelajaran. Penelitian ini bertujuan untuk mengeksplorasi persepsi mahasiswa terkait kecemasan matematis melalui penerapan Screencast-OMatic dalam pembelajaran kalkulus. Penelitian tersebut melibatkan 41 mahasiswa
\end{abstract}


dan menggunakan mixed-methods, dengan menerapkan statistik serta naratif deskriptif. Kuesioner dan pertanyaan terbuka digunakan untuk menyelidiki testimoni mahasiswa terkait video yang dibuat dengan Screencast-O-Matic serta persepsi mereka terkait dengan kecemasan matematis setelah belajar dengan video yang diberikan. Hasil penelitian menunjukkan bahwa penerapan video menggunakan Screencast-O-Matic secara bertahap menurunkan tingkat kecemasan matematis mahasiswa selama pembelajaran kalkulus. Screencast-O-Matic memberikan kesempatan bagi pendidik untuk membuat sistem perkuliahan berbasis video, dalam bentuk media audio visual untuk meminimalisir kecemasan mahasiswa. Lebih jauh, hal yang sangat penting untuk dipertimbangkan selama pembuatan video ini adalah kejelasan isi, kemudahan bagi pengguna, visualisasi yang baik, serta mudah diakses kapan dan di mana saja.

Kata Kunci: Kecemasan Matematis, Screencast-O-Matic, Video Pembelajaran, Kalkulus, Isu Pandemi

How to Cite: Soesanto, R. H., \& Dirgantoro, K. P. S. (2021). Calculus Learning Via Screencast-O-Matic During The Pandemic: An Exploration Towards Students' Perception Of Math Anxiety. MaPan : Jurnal Matematika dan Pembelajaran, 9(2), 260-279. https://doi.org/10.24252/mapan.2021v9n2a5.

\section{INTRODUCTION}

ccording to Luttenberger, Wimmer, and Paechter (2018), mathematics
anxiety is a relevant global issue that has been carried out through
many studies for approximately 60 years (Dowker, Sarkar, \& Looi, 2016). A study conducted by Wigfield and Eccles (1989) revealed that math anxiety contains two common dimensions, namely worry and emotionality. Both dimensions are related to the components of cognitive anxiety as well as feelings of stress and nervousness when faced with mathematical problems, both in school and daily life. Mathematics anxiety is also associated with a lack of numerical processing, thereby leading to low math performance (Chang \& Beilock, 2016). An interesting fact is that this type of anxiety is a factor experienced by humans in all levels of learning, ranging from young children (Vukovic, Kieffer, Bailey, \& Harari, 2013), secondary school students (Wigfield \& Eccles, 1989), to those in the university (Alves, Rodrigues, Rocha, \& Coutinho, 2016; Sevindir, Yazici, \& Yazici, 2014). Various studies have been carried out with varying solutions to mathematics anxiety at each educational level. A comprehensive study carried out by Wigfield and Eccles (1989) at primary and secondary levels disclosed that the highest mathematics anxiety 
is experienced by middle school students in grade 9 , followed by those in grades 10 to 12, while those in grade 6 experienced the least.

On the contrary, the study conducted by Vukovic, Roberts, and Wright (2013) on the concurrent and longitudinal way for children in second and third grade indicated that mathematics anxiety's detrimental effect is identified in early childhood. This also encouraged studies to determine the effect of this context on university-level students. A case study using anova tests carried out by Sevindir, Yazici, and Yazici (2014) at Kocaeli University provides empirical findings indicating that students generally feel nauseous when faced with mathematics-related problems. Furthermore, another empirical study conducted by Alves, Rodrigues, Rocha, and Coutinho (2016) towards Portuguese engineering students also showed math anxiety among students in terms of gender and type of course. Therefore, math anxiety is a factor encountered by every learner, and it does not decrease with an increase in the grade level of education. Both studies conducted on students at the university level indicate that they still encounter anxiety when faced with mathematicsrelated courses.

Mathematics anxiety is closely related to students' low learning and performance in mathematics (Ashcraft \& Faust, 1994). Although it plagues all learners at all levels, there is still hope to overcome this type of anxiety (Rozgonjuk, Kraav, Mikkor, Orav-Puurand, \& Taht, 2020), such as the enthusiasm built into a teacher when conducting a teaching lesson (Jackson \& Leffingwell, 1999) and by providing a vibrant learning atmosphere that involves students in discussions (Cooper, Downing, \& Brownell, 2018). In addition, when all students are trapped in learning conditions from home, students tend to receive minimal guidance from their teacher, which may become one of the adverse factors during mathematics learning (Soesanto \& Dirgantoro, 2021). Managing students' mathematics anxiety during the pandemic is indispensable (Simorangkir, Manalu, \& Masta, 2021), proven from several studies that have sought to overcome it. Based on the affordability of learning facilities, blended learning supported by WhatsApp is economical, simple, and tangible for reducing students' anxiety in remote areas (Nida, Usodo, \& Saputro, 2020). Educators are vying to empower various learning tools to establish a conducive and interactive learning environment that makes students feel unruffled while learning mathematics.

Specifically in calculus learning, several studies highlight anxiety problems. Awofala and Odogwu (2017) revealed that mathematics anxiety 
level was significant in calculus cognitive failures and performance among the students. The high anxiety is also attributed to several major factors, including the abstract concepts of calculus, the teaching style, and the poor analytical skills of the students (Estonanto \& Dio, 2019). This mathematics anxiety is so crucial that it will affect calculus mathematics performance (Estonanto, 2017). The use of technology has been developed and applied to control anxiety during calculus learning. A study from Batchelor (Batchelor, 2015) spells out the use of clicker during calculus learning in helping to reduce students' anxiety slightly. The utilization of mathematical applications such as GeoGebra also positively lowers calculus anxiety levels (Maskar \& Dewi, 2020).

Some approaches reduce math anxiety by reframing students' mindsets about their lack of effort in solving the problems (Samuel \& Warner, 2021). In fact, most cases of mathematics anxiety are tried to be addressed through the provision of games that are the potential to make students happier during learning (Amirnudin \& Saleh, 2020). An experimental study found that games play a role in lowering mathematical anxiety, which positively impacts mathematical performances (Novak \& Tassell, 2015). This tendency seems to make educators contend to use games as learning tools to reduce students' anxiety, though learning video is seen as one of the best practices to reduce math anxiety (Mitchell, 2018). Developing learning videos that can attract students to master mathematics would increase their motivation and alleviate their anxiety (Rachmavita, 2020). In the frame of higher education, giving a video containing lecturer explanations accompanied by various highlights about the important topics would affect students' anxiety in digesting the materials (Fitton, 2018).

The video application as learning media in mathematics is often used to improve mathematical cognitive abilities, leading to performance and learning outcomes (Boster, Meyer, Roberto, Lindsey, Smith, Inge, \& Strom, 2007; Elahwal \& Shahin, 2020; Schoenfeld, 2017). However, the development of teaching strategies in the form of videos also provides space for improved affective aspects as well as learning motivation (Rachmavita, 2020; Star \& Strickland, 2008). In the context of learning in the pandemic era, the existence of video gives students the flexibility to access at any time without time restrictions (Boster, Meyer, Roberto, Lindsey, Smith, Inge, \& Strom, 2007). Hence, it could be said that video plays a prominent role in supporting learning (Schoenfeld, 2017), especially in this crisis situation. 
In general, the handling of calculus anxiety problems during pandemic learning is organized by educators by implementing the existing mathematical software as part of teaching style modifications. There is still little effort from educators to present videos containing personal explanations as part of pedagogical strategies to facilitate online calculus learning. Therefore, this study aims to explore students' perceptions of math anxiety concerning the provision of calculus learning videos supported with Screen-O-Cast. Screencast-O-Matic is a web-based lecture system that allows lecturers to employ various highlighting, cutting, embedding, and transition tools to spice up the often quite dull experience of watching asynchronous lectures on a computer at home (Fitton, 2018). This software has been adopted by lecturers to provide recordings of explanations in calculus courses (Dewi, 2016; Foong \& Mahmud, 2019) but not close the possibility to other courses (Sudarsono, 2021).

Besides, this also can be an alternative as supplement teaching materials for distance education (Peterson, 2007). Several studies reveal the optimization of Screencast-O-Matic in the higher education of mathematics learning to enhance students' learning achievements (Dewi, 2016; Foong \& Mahmud, 2019) as well as mathematical skills and competencies (Wulandari, 2019). No studies have been found that attempt to look at students' perception of mathematics anxiety towards the implementation of Screencast-O-Matic, especially in this pandemic circumstance. Thus, it is interesting to look at their perception of mathematics anxiety through the provision of systematic explanation supported by Screencast-O-Matic software.

\section{METHODS}

According to the purposive sampling procedure, a total of 41 students from the Mathematics Education Study Program of cohort 2019 were selected. They were demographically spread into 13 provinces in Indonesia with an average age of 19-20 years. The distribution was shown in Table 1, with $46.3 \%$ of the students from North Sumatera, while the rest were spread across Java, Nusa Tenggara, Sulawesi, to Papua. 
Table 1. Participants' Demographics

\begin{tabular}{|c|c|c|c|}
\hline No. & Province & $\mathbf{n}$ & $\%$ \\
\hline 1. & North Sumatera & 19 & 46.3 \\
\hline 2. & Riau & 1 & 2.44 \\
\hline 3. & Jambi & 1 & 2.44 \\
\hline 4. & Banten & 3 & 7.32 \\
\hline 5. & Jakarta & 1 & 2.44 \\
\hline 6. & West Java & 1 & 2.44 \\
\hline 7. & Central Java & 2 & 4.88 \\
\hline 8. & East Java & 2 & 4.88 \\
\hline 9. & East Nusa Tenggara & 5 & 12.2 \\
\hline 10. & North Sulawesi & 2 & 4.88 \\
\hline 11. & Central Sulawesi & 1 & 2.44 \\
\hline 12. & South Sulawesi & 2 & 4.88 \\
\hline \multirow[t]{2}{*}{13.} & Papua & 1 & 2.44 \\
\hline & Total & 41 & 100 \\
\hline
\end{tabular}

This study was conducted in mixed methods, using statistics and narrative descriptives. The learning videos were designed using Screencast-OMatic software by paying attention to the characteristics obtained through literature studies as well as conformity with integral calculus topics. These characteristics include clarity of message (CM), stand-alone (SA), user friendly (UF), representative (R), and good visualization (GV) (Febriani, 2017; Zhang, Zhou, Briggs, \& Nunamaker, 2006). Furthermore, the videos were given to the participants $(\mathrm{n}=41)$ as the subject of this study during a weekly session. Throughout the 14 meetings in integral calculus courses, students heeded to learning videos at the beginning of the lecture session asynchronously and then continued discussing the problems provided by lecturers.

Instruments in the form of questionnaires and open-ended questions on learning videos were administered to students to determine the extent to which the quality of the video's content was based on the characteristics expressed. The questionnaire consisted of 20 questions, with a Likert scale from 1 (strongly disagree) to 4 (strongly agree), which were arranged based on five criteria of characteristics of a video. The question items passed the construct validity by expert judgments, where two experts in mathematics education were involved in the discussion to determine the video's validity. The accuracy was also supported by Pearson correlation value $r$ in each item that has exceeded $r$ table $=0.316$ and sufficient value of Cronbach Alpha, with the reliability in each criterion, as shown in Table 2. The overall video 
questionnaire's reliability value also falls into a high category $(\alpha=0.876)$, making it feasible to measure the effectiveness of integral calculus learning video.

Table 2. Validity and Reliability of Video Questionnaire

\begin{tabular}{|c|c|c|c|}
\hline Criteria & Item & Validity $(r)$ & Cronbach $(\alpha)$ \\
\hline \multirow{3}{*}{$\mathrm{CM}$} & Item 1 & .701 & \multirow{3}{*}{.826} \\
\hline & Item 2 & .549 & \\
\hline & Item 3 & .435 & \\
\hline \multirow{2}{*}{ SA } & Item 4 & .591 & \multirow{2}{*}{.708} \\
\hline & Item 5 & .402 & \\
\hline \multirow{7}{*}{ UF } & Item 6 & .611 & \multirow{7}{*}{.792} \\
\hline & Item 7 & .654 & \\
\hline & Item 8 & .466 & \\
\hline & Item 9 & .738 & \\
\hline & Item 10 & .500 & \\
\hline & Item 11 & .522 & \\
\hline & Item 12 & .425 & \\
\hline \multirow{3}{*}{$\mathrm{R}$} & Item 13 & .464 & \multirow{3}{*}{.751} \\
\hline & Item 14 & .711 & \\
\hline & Item 15 & .679 & \\
\hline \multirow{5}{*}{ GV } & Item 16 & .800 & \multirow{5}{*}{.851} \\
\hline & Item 17 & .522 & \\
\hline & Item 18 & .554 & \\
\hline & Item 19 & .546 & \\
\hline & Item 20 & .605 & \\
\hline
\end{tabular}

The second instrument was a 4 Likert scale questionnaire and the open question of mathematics anxiety scale (MAS) consisting of 20 items adopted from Zakariya (2018). By looking at two perspectives, namely learning mathematics anxiety (LMA), as many as 11 items and perception of difficulty and motivation (PDM) comprising of 9 items, was led through exploratory factor analysis (EFA) with sufficient value of Cronbach Alpha as shown at Table 3. The MAS questionnaire had a high Cronbach score $(a=0.90)$ overall. Therefore, this instrument needed to be administered to measure the level of mathematical anxiety of the student after receiving the learning video. Both questionnaires of video and MAS were given at the last weekly session of the integral calculus course. 
Table 3. Validity and Reliability of MAS Questionnaire

\begin{tabular}{|c|c|c|c|}
\hline Criteria & Item & Validity $(r)$ & Cronbach $(\alpha)$ \\
\hline \multirow{11}{*}{ LMA } & Item 1 & .363 & \multirow{12}{*}{.86} \\
\hline & Item 2 & .373 & \\
\hline & Item 3 & .406 & \\
\hline & Item 4 & .395 & \\
\hline & Item 5 & .436 & \\
\hline & Item 6 & .624 & \\
\hline & Item 7 & .624 & \\
\hline & Item 8 & .604 & \\
\hline & Item 9 & .570 & \\
\hline & Item 10 & .745 & \\
\hline & Item 11 & .554 & \\
\hline \multirow{9}{*}{ PDM } & Item 12 & .382 & \\
\hline & Item 13 & .671 & \multirow{8}{*}{.74} \\
\hline & Item 14 & .506 & \\
\hline & Item 15 & .501 & \\
\hline & Item 16 & .433 & \\
\hline & Item 17 & .333 & \\
\hline & Item 18 & .405 & \\
\hline & Item 19 & .473 & \\
\hline & Item 20 & .479 & \\
\hline
\end{tabular}

From these anxiety perspectives, the researchers would calculate the scoring average. A deep analysis using simple coding as a data analysis technique was also carried out on students' responses in open-ended questions related to the issues associated with video learning and mathematics anxiety. Besides, simple coding was also performed to look for students' perceptions based on the interactive learning videos given during weekly sessions.

\section{RESULTS AND DISCUSSION}

Students were given interactive learning videos during the weekly online learning sessions based on the scope of integral calculus lecture topics. The videos contained a core explanation collaborated with the provision of question exercises through the Moodle LMS forum, which students carried out as feedback after listening to the video's discussion. The video was made using the recording process by calculus lecturers through Screen-cast $\mathrm{O}$ software and was embedded into weekly LMS Moodle topics of integral calculus. Its duration was approximately 30 minutes and contained problems that could be 
conducted during or after listening to the video. Therefore, the video can be paused during the work of the problem or replayed, assuming there was a previous explanation that had not been fully understood. Students are actively involved in discussing calculus problems through Moodle forum with lecturers and peers during the lecture session.

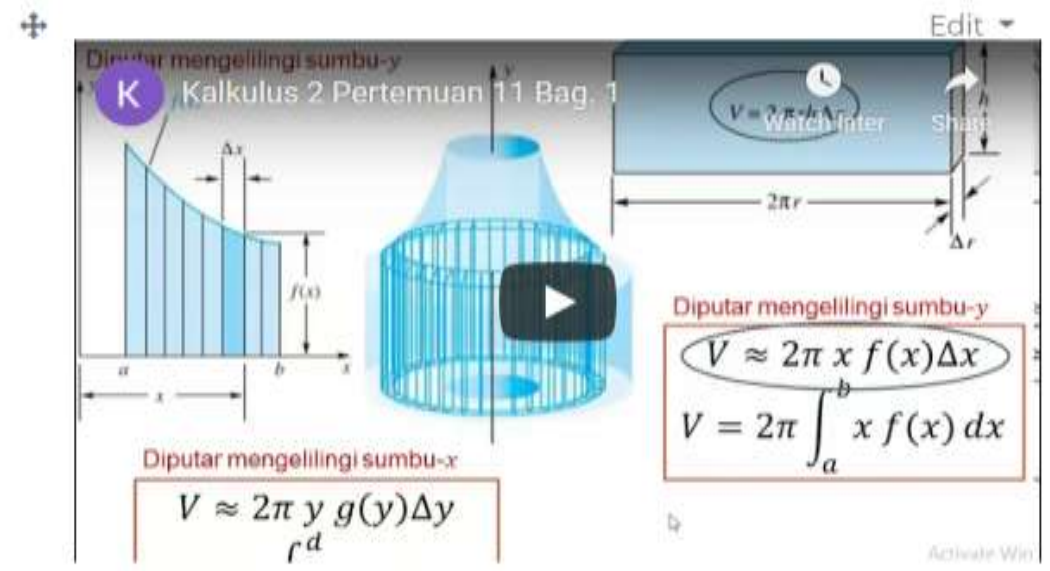

Figure 1. Sample of Interactive Video of Integral Calculus with Topic Volume Using Cylindrical Shell Method

Before the students took the final exam, they were given a questionnaire to provide an assessment and impression on the calculus learning video quality. Table 4 shows each criterion's average score in relation to the video quality according to their responses.

Table 4. Score Average of the Quality of Interactive Video

\begin{tabular}{ccc}
\hline No. & Criteria & Average \\
\hline 1. & Clarity of message (CM) & 3.48 \\
2. & Stand-alone (SA) & 2.30 \\
3. & User friendly (UF) & 3.42 \\
4. & Representative (R) & 3.45 \\
5. & Good visualization (GV) & 3.52 \\
\hline
\end{tabular}

Table 4 shows that the SA criteria were the only criterion with the lowest average gain of 2.30, while CM, UF, R, and GV obtained average scores above 3, which were 3.48, 3.42, 3.45, and 3.52, respectively. Overall, the average rating score for video quality from students' impressions was 3.35, where the score was relatively high on a scale of 4 as the highest Likert scale of this questionnaire.

An in-depth analysis was conducted as a follow-up to determine each criterion's average score using simple coding towards three open-ended 
questions from the questionnaire of video quality. The first question described how helpful the video is in guiding students through integral calculus learning. Therefore, based on the CM criterion, students stated that the video provided was beneficial because the presentation of the material was clearly figured out compared to only providing static PowerPoint that made it difficult for students to understand the learning topic's purpose. This clarity was also supported by their statements that examples and discussions in the video helped them systematically figure out the details of calculus material when studying each week.

Based on the UF criterion, students stated that they had the ability to access calculus learning videos whenever they needed, which were also compatible to watch via laptop or smartphone. Hence, students had the freedom of time and device to save and re-study the given video to prevent them from missing lectures when constrained by the network during the learning session. In fact, with an easy-to-understand explanation, they were also able to review learning on previous topics without the need to ask lecturers or peers frequently.

Based on the $\mathrm{R}$ criterion, students gave positive input related to the demonstration of sample questions and discussion inside the video. They stated that some examples of questions accompanied by discussions helped them explore the main topics learned each week. Similarly, the level of complexity given to particular problems made them understand the topic of learning comprehensively and thoroughly.

Based on the GV criterion, students also provided positive inputs related to the suitability of lecturers in choosing the background and text color as an aspect of the display, as well as animation and audio that supports the understanding of the material content. In addition, they also attested to neat visualization between slides. Various responses from the students were briefly presented in Table 5 to make it easier for readers to view their overall arguments. However, 2 students, namely S26 and S41, admitted that the difficulty in learning integral calculus was due to their typical personality because they understood the material optimally when taught directly in the classroom. Figure 2 below is one example of how students have a positive perception about good visualization being made in the video. 


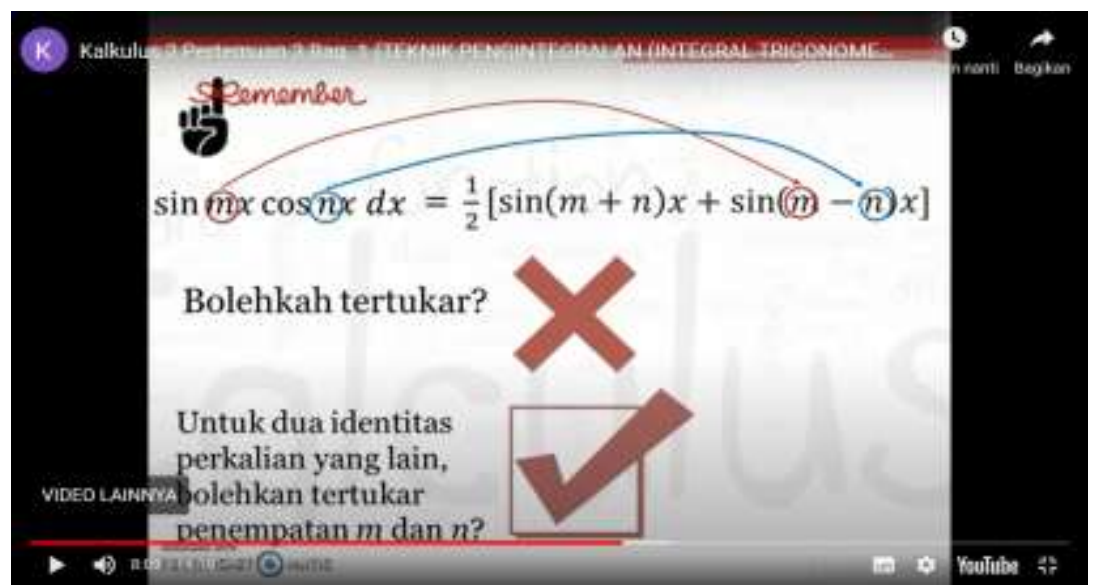

Figure 2. One Example of Good Visualization Learning Video Calculus

Regarding SA, which is the lowest average criterion, students stated that they still needed a synchronous explanation from lecturers related to some topics that were difficult to be digested. In addition to this reason, they also still felt the need to find other sources to support their understanding of learning topics. According to the argument, SA is not viewed as negative input, rather as a positive because the essence of students as autonomous learners still exists. Therefore, they do have to be actively involved in finding various resources to support their learning outcomes.

Table 5. Summary Coding of Students' Testimonies of Integral Calculus Video

\begin{tabular}{|c|c|c|}
\hline No. & Criteria & Students' Testimonies \\
\hline 1. & $\mathrm{CM}$ & $\begin{array}{l}\text { - Lecturer explanations were given clearly, detailed, and } \\
\text { systematically } \\
\text { - Lecturer explanations were easier to understand than } \\
\text { compared to static PowerPoint slides }\end{array}$ \\
\hline 2. & SA & $\begin{array}{l}\text { - Still needed explanation from lecturer synchronously } \\
\text { - Still needed other sources to understand the topic } \\
\text { comprehensively }\end{array}$ \\
\hline 3. & UF & $\begin{array}{l}\text { - Could save and access videos at any time } \\
\text { - Helpful in reviewing topics that had been studied } \\
\text { - Accessible using laptops and smartphones }\end{array}$ \\
\hline 4. & $\mathrm{R}$ & $\begin{array}{l}\text { - There were helpful examples of questions and discussions } \\
\text { - Topic coverage that suited the agenda }\end{array}$ \\
\hline 5. & GV & $\begin{array}{l}\text { - Neatly organized and structured slides } \\
\text { - Text and animation that supported the learning process } \\
\text { - There was a contrast between the color of the text and the } \\
\text { background for easy comprehension }\end{array}$ \\
\hline
\end{tabular}


The second and third questions were given as a supplementary response, successively on the integral calculus course topics, which was greatly assisted by videos and suggestions to improve the quality. Most students stated that learning calculus online using video helped them understand the topic of study on integral applications, which covered the curve area, volume, arc length, and surface revolution. Curve demonstrations and lecturers' explanations in the video, supported with several examples and discussions, made students properly understand the integral application visually and conceptually. Some students gave advice on improving video quality, such as background sound, to bring good ambience for learning calculus and clues for some challenging problems to prevent them from skipping the problems.

The success of implementing Screencast-O-Matic in making interactive videos for calculus learning is also elicited by some studies. During the pandemic, it is detected as helpful software to bring a conducive environment for calculus blended learning (Foong \& Mahmud, 2019). Other findings also portray that Screencast-O-Matic is possible to effectively build up the students' zeal to learn mathematics (Fitton, 2018; Hasan, 2020).

Educational videos were descriptively used to review the effect of students' math anxiety in studying integral calculus. Similar to the video, MAS questionnaires were also distributed to students before taking their final exam to determine their mathematics anxiety level in two dimensions, namely LMA (learning mathematics anxiety) and PDM (perception of difficulty and motivation). The questionnaire data and the average gain from each dimension of math anxiety are shown in Table 6, with average scores that are quite low, namely 2.82 and 2.51, respectively. These conditions make the total average gain for math anxiety low at 2.67 (> 2.00), which showed moderate students' math anxiety. Furthermore, the following open-ended questions provide comprehensive reasons relevant to several studies.

\section{Q1: How do you feel when you take an integral calculus course?}

Most students conveyed a feeling of confusion, distress, fear, and inadequacy when they studied integral calculus in online mode. All of these feelings indicate anxiety that occurs due to the use of complex materials as well as changes in online learning, which provides more time for selfeducation. Students of S26 stated that they were confused and stressed because they did not know where to start. While those of S19 reported that when the 
learning process was still face-to-face, they had the opportunity and courage to ask questions, however, the online process made them anxious. In addition, students of S7 stated that anxiety made them unsure of themselves during the math education study program.

In making videos, lecturers consider the content inside to create an environment where students remain engaged. It makes students, even though they still feel anxious and devastated, it does not make them lose confidence or hate integral calculus course. Fortunately, students expressed their relief over interactive videos that helped them understand the topics on integral calculus. Students of S3, S19, S21, and S29 stated that the video's provision of problems to be discussed makes the learning atmosphere remain interactive. This is in accordance with the study carried out by Vukovic, Roberts, and Wright (2013), which stated that an optimal learning environment reduces math anxiety. Another argument from Ketchum, Lafave, Yeats, Phompheng, and Hardy (2020) also reinforces that carefully designed, and interactive videos are capable of directing students to become engaged in the learning process.

\section{Q2: What difficulties that you get in learning an integral calculus course?}

In responding to this question, the respondent's answers were grouped into technical and non-technical difficulties. For technical difficulties, students complained about problems related to network instability at home. This was reasonable because not all were in places with the optimal network coverage. Other technical constraints were associated with devices, such as overheated laptops and sudden shutdown due to limited memory and compatibility. In fact, there were also some areas where students lived that had power outages periodically. Some unique technical constraints in the form of a less conducive home atmosphere also afflicted some students. For instance, those of S7, S22, S24, S31, and S38 were subjects with technical difficulties because the number of family members made the house's atmosphere too noisy, thereby making it difficult for them to learn. All of these constraints technically made it difficult for students to enjoy the integral calculus learning process online.

For non-technical difficulties, some students experienced low motivation due to the content of integral calculus topics. Therefore it took much time to review outside of lecture hours. This difficulty emerged a sense of laziness to understand the material as well as work on exercises, thereby leading to anxiety manifested in the form of neglecting the topic of learning. This fact is in line with Chang and Beilock (2016) argument, which stated that 
students with less motivation have a greater tendency to avoid math-related situations that evoke anxiety. Similar obstacles related to motivation were also experienced by students of S11 that easily felt down before starting their studies. This was triggered by the difficulty of the content inside integral calculus, coupled with the change in lectures' condition to be online.

\section{Q3: What motivates you in facing an integral calculus course?}

This last question provided a unique response from some students. Internally, the component that kept them motivated in facing courses related to integral calculus was the self-awareness that they would later become math teachers. The majority expressed this response where self-awareness created internal motivation that encouraged them to study to the maximum. Another response related to internal motivation was the curiosity to delve into the material (students of S17, S28) and the awareness that the integral calculus course was a responsibility that had to be completed (students of S8, S22, S25, S26, S31, and S35). The various responses to this question were in line with the study carried out by (Macher, Paechter, Papousek, Ruggeri, Freudenthaler, \& Arendasy, 2013), which showed an effort in their learning and proved that motivation reduces mathematics anxiety and encourages students to produce maximum performance.

Externally, most students stated that the provision of interactive videos strongly supported them in dealing with integral calculus learning topics. According to them, lecturers' ability to give interactive videos instead of static PowerPoint encouraged them to learn through explanations. Another external motivation was the support system through the role of peers in discussion sessions during lectures. Students of S1, S4, S5, S10, S14, and S18 stated that their anxiety gradually decreased with the atmosphere created through some of the video's problems requiring them to discuss. Vukovic, Roberts, and Wright (2013) stated that social-environmental aspects built-in optimal condition also enhanced motivation, which tends to reduce math anxiety. Therefore, students were able to survive during online learning conditions, which encouraged them to meet and discuss face-to-face directly.

\section{CONCLUSION}

The emergence of the Covid-19 pandemic has transformed the learning system from face-to-face to online, where student anxiety is in the spotlight for educators to create a learning environment that actively engages them. By 
optimizing Screencast-O-Matic software features, video learning media is created by educators as a breakthrough to deliver knowledge optimally. The video analysis results showed that students' anxiety gradually decreases, enabling them to be actively involved in integral calculus learning online. To achieve this, the most important factors to note in making a video are clarity of message, user friendly, good visualization, and ambience of active learning, where students can access it anytime and engage in discussions. Nevertheless, there is still the need for many educators to build up learning videos according to the students' culture and context. The study tries to provide a breakthrough in addressing students' math anxiety at the university level through video learning on integral calculus courses. Therefore, the study needs to be further developed by looking at other relevant variables in the online learning period related to mathematics, such as self-regulated learning or mathematical disposition.

This study is limited to the inability to provide a detailed explanation regarding the process of making learning videos. Therefore, the idea to use research and development $(\mathrm{R} \& \mathrm{D})$ design is very profitable to create a prototype learning video that contributes to teaching and learning mathematics online, especially at the university level. In some cases, many lecturers tend to use mathematics software, such as GeoGebra and Desmos. However, it is still rare to find a moment where lecturers create a learning media without relying on existing software. Many studies have been carried out to determine the effectiveness and optimization of using the software as well as its features. Therefore, it needs a new nuance by creating creative learning media and encouraging students to remain actively involved in difficult learning conditions without losing learning motivation.

\section{REFERENCES}

Alves, M., Rodrigues, C. S., Rocha, A. M. A. C., \& Coutinho, C. (2016). Selfefficacy, mathematics' anxiety and perceived importance: an empirical study with Portuguese engineering students. European Journal of Engineering Education, 41(1), 105-121. https://doi.org/10.1080/03043797. 2015.1095159.

Amirnudin, M. T. M., \& Saleh, S. (2020). Effectiveness of strategy Disney NLP in reducing math anxiety of students in Perak Matriculation College. Journal of Educational Research and Indigenous Studies, 2(1), 1-13. 
Ashcraft, M. H., \& Faust, M. W. (1994). Mathematics anxiety and mental arithmetic performance: An exploratory investigation. Cognition and Emotion, 8(2), 97-125. https:/ / doi.org/10.1080/02699939408408931.

Awofala, A. O. A., \& Odogwu, H. N. (2017). Assessing preservice teachers' mathematics cognitive failures as related to mathematics anxiety and performance in undergraduate calculus. Acta Didactica Napocensia, 10(2), 81-98. https://doi.org/10.24193/adn.10.2.7.

Boster, F. J., Meyer, G. S., Roberto, A. J., Lindsey, L., Smith, R., Inge, C., \& Strom, R. E. (2007). The impact of video streaming on mathematics performance. Communication Education, 56(2), 134-144. https://doi.org/ 10.1080/03634520601071801.

Chang, H., \& Beilock, S. L. (2016). The math anxiety-math performance link and its relation to individual and environmental factors: A review of current behavioral and psychophysiological research. Current Opinion in Behavioral Sciences, 10, 33-38. https://doi.org/10.1016/j.cobeha.2016.04. 011.

Cooper, K. M., Downing, V. R., \& Brownell, S. E. (2018). The influence of active learning practices on student anxiety in large-enrollment college science classrooms. International Journal of STEM Education, 5(1), 24-43. https:/ / doi.org/10.1186/s40594-018-0123-6.

Dewi, S. V. (2016). Efektivitas penggunaan media Screencast O Matic pada mata kuliah kalkulus integral terhadap hasil belajar mahasiswa. Jurnal Penelitian Pendidikan Dan Pengajaran Matematika, 2(1), 61-66. Retrieved from http://jurnal.unsil.ac.id/index.php/jp3m/article/view/Sin21/117.

Dowker, A., Sarkar, A., \& Looi, C. Y. (2016). Mathematics anxiety: What have we learned in 60 years? Frontiers in Psychology, 7, 1-16. https://doi.org/ 10.3389/fpsyg.2016.00508.

El-ahwal, M. N., \& Shahin, A. (2020). Using video-based on tasks for improving mathematical practice and supporting the productive struggle in learning math among student teachers in the faculty of education. International Journal of Instructional Technology and Educational Studies (IJITES), 1(1), 26-31. https:// doi.org/10.21608/ihites.2020.29051.1013.

Estonanto, A. J. (2017). Impact of math anxiety on academic performance in pre-calculus of senior high school. Liceo Journal of Higher Education Research, 13(2), 103-120. Retrieved from http://www. asianscientificjournals.com/new/publication/index.php/ljher/article/vi 
ew/1059.

Estonanto, A. J. J., \& Dio, R. V. (2019). Factors causing mathematics anxiety of senior high school students in calculus. Asian Journal of Education and ELearning, 7(1), 37-47. https://doi.org/10.24203/ajeel.v7i1.5701.

Febriani, C. (2017). Pengaruh Media Video terhadap Motivasi Belajar dan Hasil Belajar Kognitif Pembelajaran IPA Kelas V Sekolah Dasar. Jurnal Prima Edukasia, 5(1), 11-21. Retrieved from https://journal.uny.ac.id/ index.php/jpe/article/view/8461/pdf.

Fitton, T. (2018). Touring the online learning environment: An exploration using Screencast-O-Matic. European Journal of Open, Distance and ELearning, 28(1), 1-19. Retrieved from https://kar.kent.ac.uk/70427/1/ Touring the Online Learning Environment.pdf.

Fitton, Triona. (2018). Touring the online learning environment: An exploration using screencast-o-matic. European Journal of Open, Distance and E-Learning, 28(1), 1-19.

Foong, W. S., \& Mahmud, M. M. (2019). I can learn calculus virtually: Personalizing eLearn and Screencast-O-Matic in blended learning environment. Proceedings of the 5th International Conference on Frontiers of Educational Technologies, 3-9. https:// doi.org/10.1145/3338188.3338192.

Foong, Wong Shiau, \& Mahmud, M. M. (2019). I can learn calculus virtually: Personalizing eLearn and Screencast-O-Matic in blended learning environment. Proceedings of the 5th International Conference on Frontiers of Educational Technologies, 3-9. https:// doi.org/10.1145/3338188.3338192.

Hasan, B. (2020). Pemanfaatan google classroom dalam matakuliah menggunakan media video screencast-o-matic. Widya Wacana: Jurnal Ilmiah, 15(1), 9-15. https:/ / doi.org/10.33061/j.w.wacana.v15i1.3484.

Jackson, C. D., \& Leffingwell, R. J. (1999). The role of instructors in creating math anxiety in students from kindergarten through college. The Mathematics Teacher, 92(7), 583-586. https:// doi.org/10.5951/mt.92.7.0583.

Ketchum, C., Lafave, D. S., Yeats, C., Phompheng, E., \& Hardy, J. H. (2020). Video-based feedback on student work: An investigation into the instructor experience, workload, and student evaluations. Online Learning Journal, 24(3), 85-105. https://doi.org/10.24059/olj.v24i3.2194.

Luttenberger, S., Wimmer, S., \& Paechter, M. (2018). Spotlight on math 
Anxiety. Psychology Research and Behavior Management, 11(12), 311-322. https://doi.org/10.2147/prbm.s141421.

Macher, D., Paechter, M., Papousek, I., Ruggeri, K., Freudenthaler, H. H., \& Arendasy, M. (2013). Statistics anxiety, state anxiety during an examination, and academic achievement. British Journal of Educational Psychology, 83(4), 535-549. https://doi.org/10.1111/j.2044-8279.2012. 02081.x.

Maskar, S., \& Dewi, P. S. (2020). Praktikalitas dan efektifitas bahan ajar kalkulus berbasis daring berbantuan geogebra. Jurnal Cendekia: Jurnal Pendidikan Matematika, 4(2), 888-899. https://doi.org/10.31004/cendekia. v4i2.326.

Mitchell, K. M. (2018). Best practices to reduce math anxiety [Pepperdine University]. Retrieved from https://digitalcommons.pepperdine.edu/cgi/ viewcontent.cgi?article $=2012 \&$ context $=$ etd.

Nida, N. K., Usodo, B., \& Saputro, D. R. S. (2020). The blended learning with Whatsapp media on mathematics creative thinking skills and math anxiety. Journal of Education and Learning (EduLearn), 14(2), 307-314. https:/ / doi.org/10.11591/edulearn.v14i2.16233.

Novak, E., \& Tassell, J. (2015). Using video game play to improve educationmajors' mathematical performance: An experimental study. Computers in Human Behavior, 53, 124-130. https:/ / doi.org/10.1016/j.chb.2015.07.001.

Peterson, E. (2007). Incorporating screencasts in online teaching. International Review of Research in Open and Distance Learning, 8(3), 1-4. https:// doi.org/10.19173/irrodl.v8i3.495.

Rachmavita, F. P. (2020). Interactive media-based video animation and student learning motivation in mathematics. Journal of Physics: Conference Series, 1663, 1-7. https://doi.org/10.1088/1742-6596/1663/1/012040.

Rozgonjuk, D., Kraav, T., Mikkor, K., Orav-Puurand, K., \& Taht, K. (2020). Mathematics anxiety among STEM and social sciences students: the roles of mathematics self-efficacy, and deep and surface approach to learning. International Journal of STEM Education, 7(1), 1-11. https://doi.org/ 10.1186/s40594-020-00246-z.

Samuel, T. S., \& Warner, J. (2021). "I can math!": Reducing math anxiety and increasing math self-efficacy using a mindfulness and growth mindsetbased intervention in first-year students. Community College Journal of 
Research and Practice, 45(3), 205-222. https://doi.org/10.1080/10668926. 2019.1666063.

Schoenfeld, A. H. (2017). Uses of video in understanding and improving mathematical thinking and teaching. Journal of Mathematics Teacher Education, 20(5), 415-432. https:/ / doi.org/10.1007/s10857-017-9381-3.

Sevindir, H. K., Yazici, C., \& Yazici, V. (2014). Mathematics anxiety: A case study for Kocaeli University. Procedia - Social and Behavioral Sciences, 152, 637-641. https://doi.org/10.1016/j.sbspro.2014.09.255.

Simorangkir, M. R. R., Manalu, R. U., \& Masta, N. (2021). Prediction and analysis of mathematics anxiety disorders in adolescents during the pandemic. Solid State Technology, 64(2), 3042-3049. Retrieved from http:// solidstatetechnology.us/index.php/JSST/issue/view/52.

Soesanto, R. H., \& Dirgantoro, K. P. S. (2021). Commemorating one-year of the covid-19 pandemic: Indonesian and international issues of secondary and tertiary mathematics learning. International Journal of Studies in Education and Science (IJSES), 2(1), 18-35. https://www.ijses.net/index.php/ijses/ article/view/3.

Star, J. R., \& Strickland, S. K. (2008). Learning to observe: Using video to improve preservice mathematics teachers' ability to notice. Journal of Mathematics Teacher Education, 11(2), 107-125. https://doi.org/10.1007/ s10857-007-9063-7.

Sudarsono. (2021). Peningkatan efektivitas pengajaran kimia di masa pandemi dengan media Screencast O Matic. Khazanah Pendidikan: Jurnal Ilmiah Kependidikan, 15(1), 32-41. https:// doi.org/10.30595/jkp.v15i1.9653.

Vukovic, R. K., Kieffer, M. J., Bailey, S. P., \& Harari, R. R. (2013). Mathematics anxiety in young children: Concurrent and longitudinal associations with mathematical performance. Contemporary Educational Psychology, 38(1), 110. https:// doi.org/10.1016/j.cedpsych.2012.09.001.

Vukovic, R. K., Roberts, S. O., \& Wright, L. G. (2013). From parental involvement to children' $\mathrm{s}$ mathematical performance: The role of mathematics anxiety from parental involvement to children' $s$ mathematical performance: The role of mathematics anxiety. Early Education \& Development, 24(4), 446-467. https://doi.org/10.1080/ 10409289.2012.693430.

Wigfield, A., \& Eccles, J. S. (1989). Test anxiety in elementary and secondary 
school students. Educational Psychologist, 24(2), 159-183. https://doi.org/ 10.1207/s15326985ep2402_3.

Wulandari, S. D. (2019). Profil representasi matematis siswa dalam menyelesaikan masalah matematika dengan media screencast $\mathrm{O}$ matic. Journal of Mathematics Education and Science, 2(2), 83-87. https://doi.org/ 10.32665/james.v2i2.98.

Zhang, D., Zhou, L., Briggs, R. O., \& Nunamaker, J. F. (2006). Instructional video in e-learning: Assessing the impact of interactive video on learning effectiveness. Information and Management, 43(1), 15-27. https://doi.org/ 10.1016/j.im.2005.01.004. 